\title{
Toxicological and behavioral impacts of atrazine on Trichogrammatidae (Hymenoptera) in choice tests
}

\author{
Impactos toxicológicos y conductuales de la atrazina en Trichogrammatidae \\ (Hymenoptera) en la prueba de elección
}

\author{
GERMANO LEÃO DEMOLIN LEITE ${ }^{1}$; EDILSON PAULO RODRIGUES BISPO ${ }^{2}$; \\ ANARELLY COSTA ALVARENGA ${ }^{3}$; PAULA DAIANA DE PAULO ${ }^{4}$; MARCUS $^{2}$ \\ ALVARENGA SOARES ${ }^{5}$; PEDRO GUILHERME LEMES ${ }^{6}$
}

\begin{abstract}
${ }^{1}$ D. Sc., Insetário G. W. G. Moraes, Instituto de Ciências Agrárias, Universidade Federal de Minas Gerais, Caixa Postal 135, $39404-547$ - Montes Claros, Minas Gerais State, Brazil, germano.demolin@gmail.com, https://orcid.org/0000-0002-2928-3193. 2 Agronomist, Insetário G. W. G. Moraes, Instituto de Ciências Agrárias, Universidade Federal de Minas Gerais, Caixa Postal 135, 39404-547 - Montes Claros, Minas Gerais State, Brazil, ed-agro@hotmail.com, https:// orcid.org/0000-0003-4514-1395. ${ }^{3}$ D. Sc., Insetário G. W. G. Moraes, Instituto de Ciências Agrárias, Universidade Federal de Minas Gerais, Caixa Postal 135, 39404-547 - Montes Claros, Minas Gerais State, Brazil, aacosta@yahoo.com.br, https://orcid.org/0000-0002-0487-881X. ${ }^{4}$ D. Sc., Insetário G. W. G. Moraes, Instituto de Ciências Agrárias, Universidade Federal de Minas Gerais, Caixa Postal 135, 39404-547 - Montes Claros, Minas Gerais State, Brazil, ppaula@ gmail.com, https://orcid.org/0000-0002-6540-8969. ${ }^{5}$ D. Sc., Departamento de Agronomia, Universidade Federal dos Vales do Jequitinhonha e Mucuri, 39.100000, Diamantina, State of Minas Gerais, Brazil, marcusasoares@yahoo.com.br, https://orcid.org/0000-0002-8725-3697. ${ }^{6}$ D. Sc., Insetário G. W. G. Moraes, Instituto de Ciências Agrárias, Universidade Federal de Minas Gerais, Caixa Postal 135, 39404-547 - Montes Claros, Minas Gerais State, Brazil, pedroglemes@hotmail.com, https://orcid.org/0000-0002-1364-0424.
\end{abstract}

\begin{abstract}
Corresponding author
D. Sc., Marcus Alvarenga Soares. Departamento de Agronomia, Universidade Federal dos Vales do Jequitinhonha e Mucuri, 39.100-000, Diamantina, State of Minas Gerais, Brazil. marcusasoares@yahoo.com.br, https://orcid. org/0000-0002-8725-3697.
\end{abstract}

\section{Suggested citation}

LEITE, G. L. D.; BISPO, E. P. R.; ALVARENGA, A. C.; PAUlO, P. D.; SOARES, M. A.; LEMES, P. G. 2021. Toxicological and behavioral impacts of atrazine on Trichogrammatidae (Hymenoptera) in choice tests. Revista Colombiana de Entomología 47 (1): e8445. https://doi. org/10.25100/socolen.v47i1.8445

Received: 26-Aug-2019

Accepted: 15-Dec-2020

Published: 10-Jun-2021

Revista Colombiana de Entomología ISSN (Print): 0120-0488

ISSN (On Line): 2665-4385

https://revistacolombianaentomologia.univalle.edu.co

Open access

(c) (i) () B B-NC-SA 4.0

Publishers: Sociedad Colombiana de Entomología SOCOLEN (Bogotá, D. C., Colombia) https://www.socolen.org.co

Universidad del Valle (Cali, Colombia)

https://www.univalle.edu.co

(C) 2021 Sociedad Colombiana de Entomología SOCOLEN y Universidad del Valle - Univalle
Abstract: Weeds should be controlled with low impact methods and selective agrochemicals that have little or no effect on non-target organisms. This study aimed to evaluate the effect of the herbicide atrazine (triazine class) on 10 Trichogrammatidae (Hymenoptera) species. A female of 10 species of these natural enemies was individually placed in a glass test tube (freechoice test) with two paper cards containing 45 Anagasta (Ephestia) kuehniella (Lepidoptera: Pyralidae) eggs (treatment and control), with 10 replications. The cards were sprayed with the herbicide atrazine at $8.07 \mathrm{~L} / \mathrm{ha}$; the control was sprayed with distilled water. Parasitism by these natural enemies was allowed for $48 \mathrm{~h}$. Atrazine changes the behavior of female parasitoids, reducing the parasitism $(\approx 71 \%)$ and emergence $(\approx 74 \%)$ rates and sex ratio $(\approx$ $74 \%$ ) of the Trichogrammatidae species, except for Trichogramma galloi and T. bennetti. No females emerged from eggs parasitized by T. acacioi, Trichogrammatoidea annulata, $T$. atopovirilia, T. bruni, T. brasiliensis, T. demoraesi, and T. soaresi with atrazine. The results revealed that atrazine herbicide is harmless to $T$. bennetti and $T$. galloi, but it was moderately harmful $(80-99 \%$ reduction) to the other Trichogrammatidae species based on the parasitism and emergence rates.

Keywords: Biological control, egg parasitoid, hormesis, Trichogramma, Trichogrammatoidea, Zea mays.

Resumen: Las malezas deben ser controladas con métodos de bajo impacto y agroquímicos selectivos que afectan poco o nada a organismos no blanco. El objetivo de este estudio fue evaluar el efecto del herbicida atrazina (clase triazina) en 10 especies de Trichogrammatidae (Hymenoptera). Una hembra de 10 especies de estos enemigos naturales se colocó individualmente en un tubo de ensayo de vidrio (prueba de libre elección) con dos tarjetas de papel que contenían 45 huevos de Anagasta (Ephestia) kuehniella (Lepidoptera: Pyralidae) (tratamiento y control), con 10 repeticiones. Las tarjetas se rociaron con el herbicida atrazina a 8,07 L/ha y las del control con agua destilada. Durante $48 \mathrm{~h}$ se permitió el parasitismo de estos enemigos naturales. La atrazina cambia el comportamiento de los parasitoides hembra al reducir las tasas de parasitismo $(\approx 71 \%)$ y de emergencia $(\approx 74 \%)$ y la proporción de sexos $(\approx 74 \%)$ de las especies de Trichogrammatidae, excepto para Trichogramma galloi y T. bennetti. Ninguna hembra emergió de huevos parasitados por T. acacioi, Trichogrammatoidea annulata, T. atopovirilia, T. bruni, T. brasiliensis, T. demoraesi y T. soaresi en el tratamiento con atrazina. Los resultados de esta investigación revelan que el herbicida atrazina es inofensivo para $T$. bennetti y $T$. galloi, pero moderadamente dañino ( 80 - $99 \%$ reducción) para las otras especies de Trichogrammatidae.

Palabras clave: Control biológico, parasitoide del huevo, hormesis, Trichogramma, Trichogrammatoidea, Zea mays. 


\section{Introduction}

Corn (Zea mays L., Poaceae) is the most important cereal originating in the Americas and planted on large scale worldwide. Caterpillars and weeds are the main pests of the corn crop in Brazil (Zanuncio et al. 2013; Menezes et al. 2014). The caterpillars are controlled using insecticides, however, these products can cause environmental contamination and alternative methods are necessary to manage these insect pests (Tavares 2010). Natural enemies, especially egg parasitoids such as Trichogramma spp. (Hymenoptera: Trichogrammatidae), parasitize Spodoptera spp. (Lepidoptera: Noctuidae) and other caterpillars (Spínola-Filho et al. 2014). These organisms can reduce damage by caterpillar pests in corn crops and their parasitism on eggs prevents larvae from hatching (Gardner et al. 2011).

Weeds can reduce corn yield by up to $85 \%$ (Fickett et al. 2013; Pascoaloto et al. 2017) and herbicides are exclusively used for their control. Herbicides with atrazine (triazine class), which inhibits the photosystem II causing irreversible damage to plant cells (Chen et al. 2014), are the most widely used to control dicotyledonous plants at pre- or post-emergence in this crop (Das et al. 2010).

Herbicides can affect Trichogramma spp. parasitism because their active ingredient can penetrate the insects' cuticle (Leite et al. 2015). The herbicide's effects on parasitoids may vary with the salt quantity and type and adjuvants or their mixture, which is usually done in the field (Stefanello Júnior et al. 2011). Trichogramma spp. can be used as a model to determine the selectivity of agrochemicals to natural enemies (Menezes and Soares 2016).

This study aimed to evaluate the compatibility of parasitoids with atrazine herbicide by toxicological and behavioral impacts of parasitoid females from 10 species of Trichogrammatidae (9 Trichogramma spp. +1 Trichogrammatoidea sp.).

\section{Materials and methods}

This study was conducted at the Laboratory of Entomology and in the G.W.G. de Morais Insectarium of the Institute of Agricultural Sciences (ICA) of the "Universidade Federal de Minas Gerais (UFMG)" in Montes Claros, Minas Gerais state, Brazil, in 2014.

The experiment had a completely randomized design with 10 parasitoid species and one herbicide, besides the control, with 10 replications. Each parcel had two white paper cards ( $0.4 \mathrm{~cm}$ width $\times 2.0 \mathrm{~cm}$ length) with 45 Anagasta (Ephestia) kuehniella Zeller, 1879 (Lepidoptera: Pyralidae) eggs (200 total cards). Ten Trichogrammatidae species, commonly found in the crops in Brazil, were obtained from the Insectarium of the ICA/UFMG, with nine species of the genus Trichogramma - T. acacioi Brun, Moraes and Soares, 1984; T. atopovirilia Oatman and Platner, 1983; T. bennetti Nagaraja and Nagarkatti, 1973; T. brasiliensis Ashrnead, 1904; T. bruni Nagaraja, 1983; T. demoraesi Nagaraja, 1983; T. galloi Zucchi, 1988; T. pretiosum Riley, 1879, and T. soaresi Nagaraja, 1983, and one of the genus Trichogrammatoidea - T. annulata De Santis, 1972. The treatments were carried out with the herbicide atrazine - Gesaprim 500 Ciba-Geigy $^{\circledR}$ (recommended commercial dose for corn) and distilled water (control) (Stefanello Júnior et al. 2008; 2011).

A total of $45 \mathrm{~A}$. kuehniella eggs were glued per white paper card with $10 \%$ Arabic gum, exposed to ultraviolet radiation (UV) for $60 \mathrm{~min}$, placed in glass vials $(7.5 \mathrm{~cm}$ diameter $\times 13.0 \mathrm{~cm}$ height), sealed with plastic polyvinyl chloride (PVC) and an elastic film, and stored in a refrigerator at $5{ }^{\circ} \mathrm{C}$ and $80 \%$ R.H. for 24 h. After this period, each card was sprayed with atrazine using a Guarany ${ }^{\circledR}$ hand sprayer (Itú, São Paulo, Brazil) until runoff began (Gesaprim 500 Ciba-Geigy $^{\circledR}$ ) at $8.07{\mathrm{~L} . h a^{-1}}^{2}\left(20.16 \times 10^{-5} \mathrm{~mL}\right.$ of commercial product/card, $10.08 \times 10^{-2} \mathrm{mg}$ of active ingredient/card). The control eggs were sprayed with distilled water. The hand sprayer used was measured and had its conformity evaluated by the "Instituto Nacional de Metrologia, Qualidade e Tecnologia (INMETRO)" of the "Ministério do Desenvolvimento, Indústria e Comércio Exterior (MDIC)" of Brazil. The hand sprayer was tested three times (replicates) with a 30 min calibration process before its use. The cards were subsequently kept in the shade outdoors for $2 \mathrm{~h}$ to evaporate water excess and placed in sealed transparent glass test tubes $(1.0 \mathrm{~cm}$ diameter $\times 9.0$ $\mathrm{cm}$ height) with a newly emerged female parasitoid $(<24 \mathrm{~h}$ old, without food) for $48 \mathrm{~h}$ at 12:12 h (light:dark) photoperiod and $24.39 \pm 0.01{ }^{\circ} \mathrm{C}$ (Soares et al. 2012; 2014). Each test tube received two cards with treatment and control. The parasitism was allowed until Trichogrammatidae female death (after about six days). The experimental plot was repeated if females died before $48 \mathrm{~h}$ of parasitism.

The parasitized eggs, male and female emergence and the female-biased sex ratio (number of females $\div$ number of males + number of females) were evaluated. Parasitized eggs were those with dark colour after 20 days of subjection to parasitism, and the non-parasitized of yellow colour (Pratissoli et al. 2004; Prezotti et al. 2004). Male and female Trichogrammatidae were identified according to the antenna dimorphism (males have feathery antennae and females nailed ones) (Zuim et al. 2017), using a binocular microscope with $40 \times$ magnification.

Herbicide toxicity was classified based on the parasitism and emergence rate reduction as follows: $\mathrm{I}=$ harmless $(<30$ $\%$ reduction $), \mathrm{II}=$ slightly harmful $(30-79 \%$ reduction $)$, III $=$ moderately harmful $(80-99 \%$ reduction $)$, and $\mathrm{IV}=$ harmful (> $99 \%$ reduction) (Sterk et al. 1999). The reduction in the emergence rate of the parasitoid species was calculated as follows: $\%$ reduction $=100-$ mean $[(\%$ mean of the treatment $\div \%$ mean of the control) $\times 100]$ (Carvalho et al. 2010) The female parasitism and emergence reduction were calculated with the formula: $\%$ reduction $=100-$ mean $[(\%$ overall of the treatment with insecticide $\div \%$ overall of the control treatment $\times 100$ ]. The data were transformed to arcsine, also submitted to analysis of variance (one-way ANOVA) and the means examined using the Tukey's HSD (honest significant difference) test at $1 \%$ or $5 \%$ probability. The "sistema para análises estatísticas (SAEG)”, version 9.1 (Supplier: UFV) was the program used.

\section{Results}

Atrazine changes the behavior of parasitoid females by reducing the parasitism rate $(\approx 71 \%)$ of the Trichogrammatidae species, except for T. galloi and T. bennetti. This herbicide was harmless ( $<30 \%$ reduction) to these two natural enemies but it was moderately harmful (80 - $99 \%$ reduction) to the other parasitoid species (Table 1).

The emergence rate $(\approx 74 \%)$ of Trichogrammatidae females, except those of $T$. galloi and T. bennetti, was lower with atrazine. No parasitoid female emerged from eggs 
parasitized by T. acacioi, T. annulata, T. atopovirilia, T. bruni, T. brasiliensis, T. demoraesi, and T. soaresi that had been previously sprayed with atrazine. This herbicide was harmless to $T$. bennetti and $T$. galloi, but moderately harmful to $T$. pretiosum and harmful ( $>99 \%$ reduction) to the other Trichogrammatidae species (Table 1$)$.

The sex ratio $(\approx 74 \%)$ of ten Trichogrammatidae species, except for $T$. galloi and T. bennetti, was lower with atrazine. This herbicide was harmless to these two Trichograma species but moderately harmful to T. pretiosum, and harmful to the other Trichogrammatidae species (Table 1).

\section{Discussion}

Trichogrammatidae species showed a reduction in the parasitism behavior and the rates of emergence of females in eggs sprayed with atrazine, probably due to the effect of repellency to oviposition and also to the mortality of immatures inside the host eggs (Leite et al. 2015). The effects of atrazine-based herbicides on Trichogrammatidae species depend on the doses used and formulations of this chemical (Stefanello Júnior et al. 2008; Menezes and Soares 2016). The lower parasitism rate by the Trichogrammatidae species (repellence

Table 1. Percentage of parasitism, emergence of female and sex ratio (mean and standard error), reduction (\%) (Redu.), and classification (Class.) of Trichogrammatoidea annulata (Hymenoptera: Trichogrammatidae), and nine Trichogramma spp. (Hymenoptera: Trichogrammatidae) after treatment with atrazine. Montes Claros, Minas Gerais state, Brazil

\begin{tabular}{|c|c|c|c|c|c|c|c|c|}
\hline \multirow[b]{2}{*}{ Species } & \multicolumn{2}{|c|}{ Atrazine } & \multicolumn{2}{|c|}{ Control } & \multirow[b]{2}{*}{ Redu. } & \multirow[b]{2}{*}{ Class } & \multicolumn{2}{|c|}{$\operatorname{ANOVA}(g l=9)$} \\
\hline & Average & SE & Average & SE & & & $\mathbf{F}$ & $\mathbf{P}$ \\
\hline \multicolumn{9}{|c|}{ Percentage of parasitism } \\
\hline Trichogramma acacioi** & $7.78 \mathrm{~b}$ & 5.25 & $41.78 \mathrm{a}$ & 12.30 & 81.4 & 3 & 9.128 & 0.01445 \\
\hline Trichogrammatoidea annulata* & $6.44 \mathrm{~b}$ & 4.54 & $52.44 \mathrm{a}$ & 6.66 & 87.7 & 3 & 50.736 & 0.00006 \\
\hline Trichogramma atopovirilia** & $6.00 \mathrm{~b}$ & 6.00 & $31.56 \mathrm{a}$ & 4.59 & 81.0 & 3 & 17.080 & 0.00255 \\
\hline Trichogramma bennetti $i^{\text {n.s. }}$ & $28.00 \mathrm{a}$ & 3.73 & $33.33 \mathrm{a}$ & 9.39 & 16.0 & 1 & 0.237 & $* * * * *$ \\
\hline Trichogramma bruni** & $3.11 \mathrm{~b}$ & 3.11 & $41.78 \mathrm{a}$ & 10.42 & 92.6 & 3 & 10.158 & 0.01106 \\
\hline Trichogramma brasiliensis* & $7.78 \mathrm{~b}$ & 4.04 & $54.00 \mathrm{a}$ & 9.70 & 85.6 & 3 & 21.565 & 0.00121 \\
\hline Trichogramma demoraesi* & $2.22 \mathrm{~b}$ & 2.22 & $43.56 \mathrm{a}$ & 9.55 & 94.9 & 3 & 20.669 & 0.00139 \\
\hline Trichogramma gallo $i^{\text {n.s. }}$ & $39.11 \mathrm{a}$ & 7.33 & $35.87 \mathrm{a}$ & 6.50 & -9.03 & 1 & 0.098 & $* * * * *$ \\
\hline Trichogramma pretiosum ${ }^{* *}$ & $2.89 \mathrm{~b}$ & 2.88 & $23.11 \mathrm{a}$ & 6.86 & 87.6 & 3 & 7.904 & 0.02033 \\
\hline Trichogramma soaresi* & $2.44 \mathrm{~b}$ & 2.66 & $35.56 \mathrm{a}$ & 6.73 & 92.5 & 3 & 20.639 & 0.00140 \\
\hline \multicolumn{9}{|c|}{ Emergence of female } \\
\hline Trichogramma acacioi* & $0.00 \mathrm{~b}$ & 0.00 & $49.17 \mathrm{a}$ & 13.57 & 100.0 & 4 & 13.113 & 0.00556 \\
\hline Trichogramma annulata* & $0.00 \mathrm{~b}$ & 0.00 & $74.29 \mathrm{a}$ & 9.10 & 100.0 & 4 & 66.544 & 0.00002 \\
\hline Trichogramma atopovirilia* & $0.00 \mathrm{~b}$ & 0.00 & $65.56 \mathrm{a}$ & 8.99 & 100.0 & 4 & 53.132 & 0.00005 \\
\hline Trichogramma bennetti $i^{\text {n.s. }}$ & 85.49 a & 10.01 & $55.50 \mathrm{a}$ & 15.19 & -54.0 & 1 & 2.275 & 0.16571 \\
\hline Trichogramma bruni* & $0.00 \mathrm{~b}$ & 0.00 & $68.83 \mathrm{a}$ & 15.04 & 100.0 & 4 & 20.943 & 0.00133 \\
\hline Trichogramma brasiliensis* & $0.00 \mathrm{~b}$ & 0.00 & $72.27 \mathrm{a}$ & 12.08 & 100.0 & 4 & 35.747 & 0.00021 \\
\hline Trichogramma demoraesi* & $0.00 \mathrm{~b}$ & 0.00 & $83.91 \mathrm{a}$ & 6.66 & 100.0 & 4 & 75.424 & 0.00001 \\
\hline Trichogramma galloi ${ }^{\text {n.s. }}$ & $52.43 \mathrm{a}$ & 8.30 & $56.00 \mathrm{a}$ & 7.86 & 6.38 & 1 & 0.097 & $* * * * *$ \\
\hline Trichogramma pretiosum $* *$ & $10.00 \mathrm{~b}$ & 10.00 & $60.00 \mathrm{a}$ & 16.32 & 83.3 & 3 & 9.00 & 0.01496 \\
\hline Trichogramma soaresi ${ }^{*}$ & $0.00 \mathrm{~b}$ & 0.00 & $66.53 \mathrm{a}$ & 11.49 & 100.0 & 4 & 33.520 & 0.00026 \\
\hline \multicolumn{9}{|c|}{ Sex ratio } \\
\hline Trichogramma acacioi* & $0.00 \mathrm{~b}$ & 0.00 & $0.51 \mathrm{a}$ & 0.14 & 100.0 & 4 & 13.123 & 0.00555 \\
\hline Trichogramma annulata* & $0.00 \mathrm{~b}$ & 0.00 & $0.90 \mathrm{a}$ & 0.10 & 100.0 & 4 & 81.000 & 0.00060 \\
\hline Trichogramma atopovirilia* & $0.00 \mathrm{~b}$ & 0.00 & $0.72 \mathrm{a}$ & 0.08 & 100.0 & 4 & 63.728 & 0.00002 \\
\hline Trichogramma bennetti $i^{\text {n.s. }}$ & $0.90 \mathrm{a}$ & 0.10 & $0.60 \mathrm{a}$ & 0.16 & -50.0 & 1 & 1.976 & 0.19342 \\
\hline Trichogramma bruni* & $0.00 \mathrm{~b}$ & 0.00 & $0.69 \mathrm{a}$ & 0.15 & 100.0 & 4 & 20.948 & 0.00133 \\
\hline Trichogramma brasiliensis* & $0.00 \mathrm{~b}$ & 0.00 & $0.80 \mathrm{a}$ & 0.13 & 100.0 & 4 & 36.000 & 0.00020 \\
\hline Trichogramma demoraesi* & $0.00 \mathrm{~b}$ & 0.00 & $0.90 \mathrm{a}$ & 0.10 & 100.0 & 4 & 81.000 & 0.00000 \\
\hline Trichogramma gallo $i^{\text {n.s. }}$ & $0.75 \mathrm{a}$ & 0.09 & $0.82 \mathrm{a}$ & 0.09 & 8.54 & 1 & 0.209 & $* * * * *$ \\
\hline Trichogramma pretiosum $* *$ & $0.10 \mathrm{~b}$ & 0.10 & $0.60 \mathrm{a}$ & 0.16 & 83.3 & 3 & 9.000 & 0.01495 \\
\hline Trichogramma soaresi ${ }^{*}$ & $0.00 \mathrm{~b}$ & 0.00 & $0.80 \mathrm{a}$ & 0.13 & 100.0 & 4 & 36.000 & 0.00020 \\
\hline
\end{tabular}

Means followed by a lower letter per line do not differ by the Tukey's HSD (honest significant difference) test $\left({ }^{*} \mathrm{P}<0.01,{ }^{* *} \mathrm{P}<0.05\right)$. n.s. $=$ not significant by Variance Analyses (ANOVA) $(\mathrm{P}>0.05)$. Classification of toxicity index: class $\mathrm{I}=$ harmless $(<30 \%$ reduction $)$, class $\mathrm{II}=$ slightly harmful $(30 \%-79 \%$ reduction $)$, class III = moderately harmful $(80 \%-99 \%$ reduction $)$, and class IV $=$ harmful $(>99 \%$ reduction). 
effect of atrazine), except in $T$. galloi and T. bennetti, can be explained by the ability of these species to detect nocive substances, rejecting hosts and, consequently, reducing parasitism. Trichogramma galloi may be more resistant to pesticides as chlorantraniliprole (insecticide, anthranilic diamides chemical group), sulfometruron methyl (plant growth regulator, sulfonylurea chemical group), and triflumuron (insecticide, benzoylurea chemical group) that were demonstrated to not repel or reduced its parasitism rate in a previous Brazilian study (Antigo et al. 2013). Tolfenpyrad (insecticide, pyrazole chemical group) reduced the foraging behavior of $T$. pretiosum but this was not found with 11 other pesticides, indicating that parasitoids could successfully forage on eggs treated with many pesticides in a Pakistani study (Khan et al. 2015).

The lack of impact of atrazine on the emergence of T. galloi and $T$. bennetti females may be due to its detoxification capacity (Stefanello Júnior et al. 2011; Oliveira et al. 2014). This indicates greater resistance of these parasitoid species to atrazine. Primoleo ${ }^{\circledR}$ (herbicide, triazine chemical group) and Siptran $500 \mathrm{SC}^{\circledR}$ (herbicide, triazine chemical group) were classified as class I (harmless, $<30 \%$ reduction) and the Gesaprim $\mathrm{GrDA}^{\circledR}$ (herbicide, triazine chemical group) as class II (slightly harmful, 30 - $79 \%$ reduction) for the mortality of T. pretiosum adults in a previous Brazilian study (Stefanello Júnior et al. 2008). The survival of the predator Podisus nigrispinus Dallas, 1851 (Hemiptera: Pentatomidae), the parasitoids $T$. atopovirilia, T. bennetti and T. brunni, and soil arthropods such as Collembola, mites (Acari), and ants (Hymenoptera: Formicidae) was lower than $50 \%$ when submitted to herbicides with atrazine in three different Brazilian studies (Pereira et al. 2005; Lins et al. 2007; Menezes et al. 2012). The higher emergence rate of $T$. pretiosum, $T$. demoraesi, $T$. galloi, and $T$. soaresi with atrazine in a no-choice test in a Brazilian study may be related to the "hormesis" phenomenon (Leite et al. 2015) where in sublethal quantities of a stressor benefit an organism (Pratissoli et al. 2010). This hypothesis is possible, especially considering that the herbicide quantity reaching the parasitoid inside the host egg is very low (Leite et al. 2015). However, the "hormesis" phenomenon with these four Trichogramma species was not detected in this work (free-choice test), possibly due to the reduction of the parasitism and, consequently, female emergence rate.

No impact of atrazine on $T$. galloi and $T$. bennetti sex ratio may show, as explained before, host egg protection and detoxification capacity (Stefanello Júnior et al. 2011; Oliveira et al. 2014), but it needs to be better studied to understand the responses of both parasitoids to the herbicide. The emergence of Aedes (= Stegomyia) aegypti L., 1762 (Diptera: Culicidae) and Aedes (= Stegomyia) albopictus Skuse, 1894 (Diptera: Culicidae) were higher with atrazine than with glyphosate (herbicide, glycine chemical class) in a North American study. The sex ratio was distorted with male bias observed in the control and glyphosate treatments, but not with atrazine (Bara et al. 2014). The emergence period for both sexes of these two mosquito species was longer with atrazine than with glyphosate and in the control (Bara et al. 2014). The reduced sex ratio of T. bruni, T. atopovirilia and T. bennetti and higher values for $T$. demoraesi and $T$. soaresi in no-choice tests in a Brazilian study (Leite et al. 2015) shows that the impact of atrazine, a widely used herbicide, on life-history traits as reported for mosquitoes (Bara et al. 2014) depends on the species of insect.

\section{Conclusions}

The parasitoids $T$. bennetti and $T$. galloi showed adequate values of parasitism and emergence in eggs previously sprayed with atrazine and can be used simultaneously with the application of this herbicide.

Trichogramma acacioi, T. annulata, T. atopovirilia, $T$. bruni, T. brasiliensis, $T$. demoraesi, and $T$. soaresi species should be released, after the residual toxicity period of the herbicide, to avoid reducing its efficiency in biological control.

\section{Acknowledgments}

To the Brazilian agencies "Conselho Nacional de Desenvolvimento Cientifico e Tecnológico (CNPq)" and "Fundação de Amparo à Pesquisa do Estado de Minas Gerais (FAPEMIG)" for scholarships and financial support. This study was financed in part by the Coordenação de Aperfeiçoamento de Pessoal de Nível Superior - Brasil (CAPES) - Finance Code 001.

\section{Literature cited}

ANTIGO, M. R.; OLIVEIRA, H. N.; CARVALHO, G. A.; PEREIRA, F. F. 2013. Repellence of pesticides used in sugarcane and their effects on the emergence of Trichogramma galloi. Revista Ciência Agronômica 44 (4): 910-916. https://doi.org/10.1590/ S1806-66902013000400030

BARA, J. J.; MONTGOMERY, A.; MUTURI, E. J. 2014. Sublethal effects of atrazine and glyphosate on life history traits of Aedes aegypti and Aedes albopictus (Diptera: Culicidae). Parasitology Research 113: 2879-2886. https://doi.org/10.1007/s00436-0143949-y

CARVALHO, G. A.; GODOY, M. S.; PARREIRA, D. S.; REZENDE, D. T. 2010. Effect of chemical insecticides used in tomato crops on immature Trichogramma pretiosum (Hymenoptera: Trichogrammatidae). Revista Colombiana de Entomología 36 (1): 1015. http://www.scielo.org.co/pdf/rcen/v36n1/v36n1a03.pdf

CHEN, L.; ZHU, X.; WANG, Y.; CHEN, L.; DUAN, Y. 2014. Proteomic analysis of the bacterial induction of resistance to atrazine in soybean leaves. Acta Physiologiae Plantarum 36: 22292241. https://doi.org/10.1007/s11738-014-1601-1

DAS, T. K.; SAKHUJA, P. K.; ZELLEKE, H. 2010. Herbicide efficacy and non-target toxicity in highland rainfed maize of Eastern Ethiopia. International Journal of Pest Management 56 (4): 315 325. https://doi.org/10.1080/09670874.2010.497872

FICKETT, N. D.; BOERBOOM, C. M.; STOLTENBERG, D. E. 2013. Predicted corn yield loss due to weed competition prior to postemergence herbicide application on Wisconsin farms. Weed Technology 27 (1): 54-62. https://doi.org/10.1614/WT-D-1200097.1

GARDNER, J.; HOFFMANN, M. P.; PITCHER, S. A.; HARPER, J. K. 2011. Integrating insecticides and Trichogramma ostriniae to control European corn borer in sweet corn: Economic analysis. Biological Control 56 (1): 9-16. https://doi.org/10.1016/j. biocontrol.2010.08.010

KHAN, M. A.; KHAN, H.; RUBERSON, J. R. 2015. Lethal and behavioral effects of selected novel pesticides on adults of Trichogramma pretiosum (Hymenoptera: Trichogrammatidae). Pest Management Science 71 (12): 1640-1648. https://doi. org/10.1002/ps.3972

LEITE, G. L. D.; PAULO, P. D.; ZANUNCIO, J. C.; ALVARENGA, A. C.; SOARES, M. A.; TAVARES, W. S.; TUFFI-SANTOS, L. D.; SPÍNOLA-FILHO, P. R. C. 2015. Effects of atrazine-based herbicide on emergence and sex ratio of Trichogrammatidae (Hymenoptera). Florida Entomologist 98 (3): 899-902. https:// doi.org/10.1653/024.098.0313 
LINS, V. L.; SANTOS, H. R.; GONÇALVES, M. C. 2007. The effect of the glyphosate, 2,4-D, atrazine e nicosulfuron herbicides upon the edaphic Collembola (Arthropoda: Ellipura) in a no tillage system. Neotropical Entomology 36 (2): 261-267. https://doi. org/10.1590/S1519-566X2007000200013

MENEZES, C. W. G.; SOARES, M. A. 2016. Impacts of the control of weeds and herbicides applied to natural enemies. Revista Brasileira de Herbicidas 15 (1): 2-13. https://doi.org/10.7824/ rbh.v1i1.407

MENEZES, C. W. G.; SANTOS, J. B.; ASSIS JÚNIOR, S. L.; FONSECA, A. J.; FRANÇA, A. C.; SOARES, M. A.; FERNANDES, A. F. 2012. Seletividade de atrazine e nicosulfuron a Podisus nigrispinus (Heteroptera: Pentatomidae). Planta Daninha 30 (2): 327-334. https://doi.org/10.1590/S0100-83582012000200011

MENEZES, C. W. G.; TAVARES, W. S.; SOUZA, E. G.; SOARES, M. A.; SERRÃO, J. E.; ZANUNCIO, J. C. 2014. Effects of crude extract fractions of Adenocalymma nodosum (Bignoniaceae) on duration of pupa stage emergence of Tenebrio molitor (Coleoptera: Tenebrionidae) and phytotoxicity on vegetable crops. Allelopathy Journal 33 (1): 141-149.

OLIVEIRA, H. N.; ANTIGO, M. R.; CARVALHO, G. A.; GLAESER, D. F. 2014. Effect of selectivity of herbicides and plant growth regulators used in sugarcane crops on immature stages of Trichogramma galloi (Hymenoptera: Trichogrammatidae). Planta Daninha 32 (1): 125-131. https://doi.org/10.1590/S010083582014000100014

PASCOALOTO, I. M.; ANDREOTTI, M.; CRUZ, S. S.; SABBAG, O. J.; BORGHI, E.; LIMA, G, C.; MODESTO, V. C. 2017. Economic analysis of sorghum consortia with forages or with dwarf pigeon pea succeeded by soybean or corn. Pesquisa Agropecuária Brasileira 52 (10): 833-840. https://doi.org/10.1590/ s0100-204x2017001000002

PEREIRA, J. L.; SILVA, A. A.; PICANÇO, M. C.; BARROS, E. C.; JAKELAITIS, A. 2005. Effects of herbicide and insecticide interaction on soil entomofauna under maize crop. Journal of Environmental Science and Health, Part B 40 (1): 45-54. https:// doi.org/10.1081/PFC-200034212

PRATISSOLI, D.; OLIVEIRA, H. N.; GONÇALVES, J. R.; ZANUNCIO, J. C.; HOLTZ, A. M. 2004. Changes in biological characteristics of Trichogramma pretiosum (Hym.: Trichogrammatidae) reared on eggs of Anagasta kuehniella (Lep.: Pyralidae) for 23 generations. Biocontrol Science and Technology 14 (3): 313-319. https://doi.org/10.1080/09583150310001639196

PRATISSOLI, D.; MILANEZ, A. M.; BARBOSA, W. F.; CELESTINO, F. N.; ANDRADE, G. S.; POLANCZYK. R.A. 2010. Side effects of fungicides used in cucurbitaceous crop on Trichogramma atopovirilia Oatman \& Platner (Hymenoptera: Trichogramatidae). Chilean Journal of Agricultural Research 70 (2): 323-327. https://doi.org/10.4067/S0718-58392010000200016

PREZOTTI, L.; PARRA, J. R. P.; VENCOVSKY, R.; COELHO, A. S. G.; CRUZ, I. 2004. Effect of the size of the founder population on the quality of sexual populations of Trichogramma pretiosum, in laboratory. Biological Control 30 (2): 174-180. https://doi.org/10.1016/j.biocontrol.2004.01.011

SOARES, M. A.; LEITE, G. L. D.; ZANUNCIO, J. C.; SÁ, V. G. M.; FERREIRA, C. S.; ROCHA, S. L.; PIRES, E. M.; SERRÃO, J. E. 2012. Quality control of Trichogramma atopovilia and Trichogramma pretiosum (Hym.: Trichogrammatidae) adults reared under laboratory conditions. Brazilian Archives of Biology and Technology 55 (2): 305-311. https://doi.org/10.1590/S151689132012000200018

SOARES, M. A.; LEITE, G. L. D.; ZANUNCIO, J. C.; FERREIRA, C. S.; ROCHA, S. L.; SÁ, V. G. M. 2014. Assessment of Trichogramma species (Hymenoptera: Trichogrammatidae) for biological control in cassava (Manihot esculenta Crantz). Acta Scientiarum. Agronomy 36 (4): 403-408. https://doi. org/10.4025/actasciagron.v36i4.17744
SPÍNOLA-FILHO, P. R. C.; LEITE, G. L. D.; SOARES, M. A.; ALVARENGA, A. C.; PAULO, P. D.; TUFFI-SANTOS, L. D.; ZANUNCIO, J. C. 2014. Effects of duration of cold storage of host eggs on percent parasitism and adult emergence of each of ten Trichogrammatidae (Hymenoptera) species. Florida Entomologist 97 (1): 14-21. https://doi.org/10.1653/024.097.0102

STEFANELLO JÚNIOR, G. J.; GRÜTZMACHER, A. D.; GRÜTZMACHER, D. D.; LIMA, C. A. B.; DALMOZO, D. O.; PASCHOAL, M. D. F. 2008. Seletividade de herbicidas registrados para a cultura do milho a adultos de Trichogramma pretiosum (Hymenoptera: Trichogrammatidae). Planta Daninha 26 (2): 343-351. https://doi.org/10.1590/S0100-83582008000200010

STEFANELLO JÚNIOR, G. J.; GRÜTZMACHER, A. D.; PASINI, R. A.; BONEZ, C.; MOREIRA, D. C.; SPAGNOL, D. 2011. Seletividade de herbicidas registrados para a cultura do milho aos estádios imaturos de Trichogramma pretiosum (Hymenoptera: Trichogrammatidae). Planta Daninha 29 (special issue): 10691077. https://doi.org/10.1590/S0100-83582011000500014

STERK, G.; HASSAN, S. A.; BAILLOD, M.; BAKKER, F.; BIGLER, F.; BLÜMEL, S.; BOGENSCHÜTZ, H.; BOLLER, E.; BROMAND, B.; BRUN, J.; CALIS, J.N.M.; COREMANS-PELSENEER, J.; DUSO, C.; GARRIDO, A.; GROVE, A.; HEIMBACH, U.; HOKKANEN, H.; JACAS, J.; LEWIS, G.; MORETH, L.; POLGAR, L.; ROVESTI, L.; SAMSOE-PETERSON, L.; SAUPHANOR, B.; SCHAUB, L.; STÄUBLI, A.; TUSET, J.J.; VAINIO, A.; VAN DE VEIRE, M.; VIGGIANI, G.; VIÑUELA, E.; VOGT, H. 1999. Results of the seventh joint pesticide testing programme carried out by the IOBC/WPRS-Working Group "Pesticides and Beneficial Organisms". BioControl 44: 99-117. https://doi.org/10.1023/A:1009959009802

TAVARES, W. S. 2010. Custos de uma Biofábrica de Trichogramma pretiosum Riley para o Controle da Lagarta-do-Cartucho no Milho. EntomoBrasilis 3 (2): 49-54. https://doi.org/10.12741/ ebrasilis.v3i2.76

ZANUNCIO, J. C.; MATOS NETO, F. C.; TAVARES, W. S.; CRUZ, I.; LEITE, G. L. D.; SERRÃO, J. E. 2013. Functional and numerical responses and reproduction of Campoletis flavicincta parasitizing Spodoptera frugiperda caterpillars. Acta Scientiarum. Agronomy 35 (4): 419-426. https://doi.org/10.4025/ actasciagron.v35i4.15871

ZUIM, V.; RODRIGUES, H. S.; PRATISSOLI, D.; TORRES, J. B. 2017. Thermal requirements and performance of the parasitoid Trichogramma pretiosum (Hymenoptera: Trichogrammatidae) on Helicoverpa armigera (Lepidoptera: Noctuidae) eggs under variable temperatures. Environmental Entomology 46 (5): 11561164. https://doi.org/10.1093/ee/nvx132

\section{Origin and funding}

The presente study was result of a project funded by "Conselho Nacional de Desenvolvimento Científico e Tecnológico" (CNPq) and "Fundação de Amparo à Pesquisa do Estado de Minas Gerais" (FAPEMIG). This study was financed in part by the Coordenação de Aperfeiçoamento de Pessoal de Nivel Superior - Brasil (CAPES) - Finance Code 001.

\section{Author contribution}

Edilson Paulo Rodrigues, Germano Leão Demolin Leite, Anarelly Costa Alvarenga and Paula Daiana De Paulo carried out the experiments.

Germano Leão Demolin Leite, Pedro Guilherme Lemes and Marcus Alvarenga Soares analyzed the data and performed the interpretation of the results.

Germano Leão Demolin Leite and Marcus Alvarenga Soares wrote the manuscript.

Germano Leão Demolin Leite supervised the project. 